\title{
IUGS FINANCIAL STATEMENT FOR 1987, BUDGET FOR 1988
}

Receipts and Expenditures for 1987 Compared to 1986 and Estimates for 1988

(Information provided by IUGS Treasurer, Dr. J.A. Reinemund, Note 1)

\section{RECEIPTS}

- Transfers from Unesco for IGCP contracts (Note 2)

- Membership dues (Note 3)

- Special grants and contracts (Note 4)

- Allocations from ICSU (Note 5)

- Income from publications:

- Episodes subscriptions and related income

- Royalties and IUGS Publications sales

- Bank interest and dividends

- Miscellaneous receipts (Note 6)

\section{PAYMEN'TS}

- Scientific activities

- IGCP (Note 7)

- IGCP supplements from IUGS (Note 8)

- IUGS Commissions, Committees (Schedule A)

- Special contractual programs (Note 9)

- Research Development Board and Program (Note 10)

- Remote Sensing Advisory Board

- IUGS Affiliated Organizations (Schedule B)

- Inter-Union Commission on the Lithosphere

- Representation at scientific meetings

- Routine meetings

- 1986: Executive Committee meeting \& seminar, Washington

- 1987: Executive Committee meeting, Paris (Note 12)

1 1988: Executive Committee meeting, Guangzhou and Bureau meetings (Note 12 )

- Publications

- Episodes printing and related costs (Note 13)

- Other IUGS publications: printing costs

- Promotion and displays

- Publishers Advisory Board and Miscellaneous costs

- Administrative expenses

- Salaries and related charges (Note 13)

- Operating costs and supplies

- Miscellaneous charges

- Bank charges, loss on exchange

- Payments to ICSU

- IUGS annual contribution to ICSU (Note 5)

- IUGS contribution to Committee on the Teaching of Science

- IUGS dues to ICSTI

STATUS OF ACCOUNTS (As of December 31 each year)

Episodes account (Ottawa)

Secretary-General's account (Trondheim) (Note 14)

Treasurer's operational account (Reston) (Note 14)

IUGS reserve account (Reston)

$$
\begin{array}{r}
234,611 \\
8,900 \\
65,732 \\
30,093 \\
18,603 \\
10,366 \\
19,000 \\
22,851 \\
9,413 \\
\\
26,827 \\
\\
\\
\\
34,314 \\
4,641 \\
3,213 \\
1,602 \\
\\
32,676 \\
25,137 \\
3,709 \\
456 \\
\\
4,588 \\
800
\end{array}
$$

TOTAL

$\$ \overline{557,532}$
1987

(\$US)

181,147

164,140

182,285

26,139

47,457

8,059

4,816

5,289

$\$ \longdiv { 6 1 9 , 3 3 2 }$
Budget

for

1988

(\$US)

180,000

175,000

175,000

20,000

45,000

10,000

5,000

25,000

$\$ \longdiv { 6 3 5 , 0 0 0 }$
20,254

$-18,858$

50,511

61,282

TOTAL \$\$11,189

$$
\begin{array}{r}
185,500 \\
79,500 \\
77,261 \\
52,151 \\
35,342 \\
5,292 \\
24,100 \\
31,375 \\
3,141
\end{array}
$$

27,241

41,773

7,176

3,012

2,112

30,359

21,337

2,847

3,940

4,178

400

1,500

$\$ \lcm{169,537}$

21,094

$-29,379$

41,624

59,645

$\$ \underline{\underline{92,984}}$
180,000

\begin{tabular}{|c|c|}
\hline 114,510 & 113,505 \\
\hline 56,837 & 55,845 \\
\hline 57,673 & 57,660 \\
\hline 130,532 & 113,189 \\
\hline$-17,343$ & $-20,205$ \\
\hline 113,189 & 92,984 \\
\hline 57,673 & 57,660 \\
\hline 170,862 & $\$ \overline{150,644}$ \\
\hline
\end{tabular}
100,000

92,000

35,000

28,000

5,000

29,000

15,000

5,000

25,000

40,000

7,000

3,000

3,000

35,000

22,000

5,000

600

4,500

500

$\$ \underline{\underline{635,000}}$

\section{SUMMARY}

Accounts receivable December 31 (Note 14)

Accounts payable on December 31

Difference

Accumulated balance at January 1

Plus excess of receipts over expenditures

Accumulated balance at December 31

Plus difference between accounts receivable and payable

NET FINANCIAL ASSETS AT DECEMBER 31 


\section{Notes to the 1986 and 1987 Financial Statement}

Note 1: This Statement has been prepared by the Treasurer in accordance with the Statute and Bylaws of the Union. Receipts and payments have been reor IUGS offices. In those offices outside the U.S.A. the accounts have been converted to U.S. dollars at year end, based on official ICSU rates of exchange at the year end. Receipts and payments involving exchanges of currency during the year have used the official ICSU rate of exchange at the time of transaction.

In order to provide a basis for comparison, relevant information on receipts and payments is included for 1986, as well as the estimated income and project expenditures (budget) for 1988. This statement is a consolidation of information from accounts maintained solely by IUGS in Ottawa, Trondheim, and Reston, but does not include joint-use local currency accounts in Moscow and Sydney.

This statement does not reflect the costs borne by member countries in support of activities and operations of the Union except for those costs covered by transfers of funds under special grants listed in Note 4. Also, this statement does not show details of accounts receivable or payable at the end of the year.

Note 2: Funds are transferred from Unesco each year under contracts between Unesco and IUGS covering IGCP projects for which allocations are made during the year. However, each year there are delays in transfer of budgeted funds from Uneseo for some projects that do not start at the scheduled time, as well as carryover receipts from Unesco for projects funded in the previous year. The total funds received in 1987 included $\$ 36,450$ in allocations for contracts issued in 1986 and $\$ 1,500$ for contracts issued in 1985 . 1988 estimates are based on assumptions that some rmounts allocated by Unesco for IGCP projects in 1988 will not be received until 1989 , but that carry-over allocations for 1987 will be received by IUGS during 1988 . Total amount of IGCP project allocations tentatively budgeted by Unesco for contracts issued in 1988 is $\$ 168,200$.

Note 3: Member countries pay annual contributions according to their selected category of membership as outlined in the following table:

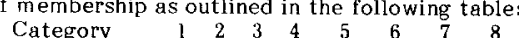

Category

Units of

$\begin{array}{lllllllll}\text { Contribution* } & 1 & 2 & 4 & 7 & 12 & 20 & 35 & 70\end{array}$

(*valued at U.S. $\$ 300$ per unit as of July 10 , 1980). 1987 Receipt figures include $\$ 11,805$ paid in 1987 covering membership fees for prior years and $\$ 10,500$ in advance payments of $1988 \mathrm{mem-}$ bership fees. At December 31st, 1987 , the unpaid memberships for 1981-1987 totalled $\$ 63,142$.

Note 4: Receipts from special grants and contracts during 1987 included:

- Unesco contracts for remote sensing

program (GARS) in Africa

and South America

9,000

Unesco contracts for deposit modelling

workshops in Brazil and Chile

- Canada grant for President's of fice

expenses

9,500

U.S. grant for Treasurer's office expenses

15,000

1,000

U.K. grant to support IGCP and related projects

U.S. grant to support IGCP and related projects

100,000

Grants from IUGS associates to support IUGS programs TOTAL

$\frac{2,500}{182,285}$

Estimate for 1988 includes anticipated special contributions from the United Kingdom and the United States to be used mostly as supplements for IGCP projects.
Note 5: IUGS received $\$ 10,139$ from ICSU in 1987 as apportioned amount of the Uneseo subvention to ICSU. IUGS also recelved $\$ 9,000$ from ICSU in 1987 as supplemental grants to support research projects under the IUGS Research Development Program. IUGS pays an annual subvention to ICSU based on $2.5 \%$ of annual subvention to ICSU based
receipts for IUGS membership fees.

Note 6: $F$ unds in this category included deposits of $\$ 3,345$ in refunds of unspent allocations to IGCP projects and $\$ 1,944$ in refunds of prior advances to IUGS constituent bodies.

Note 7: Funds transferred in 1987 included $\$ 170,500$ to [GCP projects authorized in 1987 and $\$ 15,000$ to IGCP projects authorized in 1986 .

Note 8: IUGS supplements in 1987 were distributed to 35 IGCP projects having high priority funding requirements.

Note 9: Funds paid under this category in 1987 were in support of the Geologic Applications of Remote Sensing (GARS) program $(\$ 21,000)$ and the Mineral Deposit Modelling Program $(\$ 21,305)$ both of which were funded partly through special contracts with Unesco, and the Basin Analysis (Resource Assessment) program funded partly by Norway $(\$ 9,846)$

Note 10: Funds pajd under this eategory in 1987 included $\$ 11,612$ for the Advisory Board for Research Development and allocations of $\$ 5,000$ for Pannonian Basin, $\$ 16,730$ for Cireum-Atlantic and $\$ 2,000$ for Volcanic Hazard Mitigation projects.

Note 11: Funds alloeated to the Commission on Stratigraphy are divided among 24 constituent subcommissions and working groups (see list in Episodes vol. 1983 , no. 4, p. 67) according to priorities established by the Commission.

Some of the budgeted amounts for 1987 as shown in schedules $A$ and $B$ differ from originally allocated by the Executive Committee because of subsequent allocations to meet demonstrated needs.

Note 12: 1987 figures include costs for the IUGS Seminar in Guangzhou, as well as for the IUGS Nominating Committee and Bureau meetings in Paris and Ottawa.

Note 13: Salary costs for Episodes are shown under "Administrative Expenses" inasmuch as the Episodes staff provides considerable service not only for the publication program but also for IUGS publicity, representation, and liaison. Additional services and space for IUGS offices in Ottawa, Trondheim and Reston are provided by Canada, Norway and the United States respectively.

Note 14: In calculating "Accounts Receivable", $\$ 12,500$ in unpaid membership fees for year prior to 1981 have not been included owing to considerable uncertainty that they will be received.

As shown in this listing, the Trondheim account had a deficiency of $\$ 29,379$ as of December 31 , 1987, pending the transfer of this amount from the Treasurer's operational account in Reston. Amounts shown for the IUGS Reserve Account are estimates based on current (year end) marke value. The drop in value of the Account from 1986 to 1987 reflects the drop in the stock market in 1987, and change-over to a certificate of deposit, the interest on which will not be included in the Account until the certificate included
SCHEDULE A

PAYMENTS TO COMMISSIONS, BOARDS AND COMMITTEES (a)

$\begin{array}{lll}1986 \quad 1987 \quad \text { Budget } & 1988\end{array}$

$\begin{array}{llr}1986 & 1987 & 1988 \\ \text { (\$US) } & \text { (\$US) } & \text { (\$US) }\end{array}$

Commission on Igneous

and Metamorphic

Petrogenesis

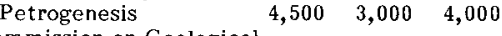

Documentation $\quad 1,500 \quad 3,000 \quad 3,000$

Commission on the History

of Geological Sciences $1,500 \quad 2,000 \quad 2,000$

Commission for Marine

Geology

$4,500 \quad 7,000 \quad 10,000$

Commission on Storage,

Automatic Processing

and Retrieval of

Geological Date

$7,000 \quad 8,000 \quad 8,500$

Commission on

Systematics in

Petrology

(2)

Commission on Tectonics

(Note 12)

$7,966 \quad 11,800 \quad 11,000$

Commission on Stratigraphy

(Note 12)

$2,000 \quad 5,000$

Commission on

Comparativ

Planetology

Commission on Global

Sedimentary Geology $\quad 2,500 \quad 9,511 \quad 16,000$

Commission on Geological

Teaching

$25,300 \quad 27,950 \quad 28,000$

orking Group on

Petroleum Resource

Assessment

TOTAL

7,966

$\overline{65,732} \overline{77,261} \overline{92,000}$

(a) Expenditures for Advisory Boards and related activities are included in general listing of payments. Expenditures for the Working Group on Petroleum Resource Assessment are included in the expenditures for Basin Analysis (Note 9).

SCHEDULE B

PAYMENTS TO AFFILIATED ORGANIZATIONS

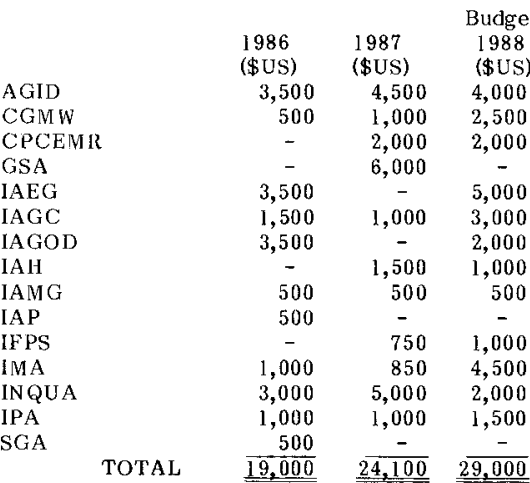

